\title{
Muslim Romance in Diaspora: Leila Aboulela's "Minaret" (2005) and the Ethics of Reading in the West
}

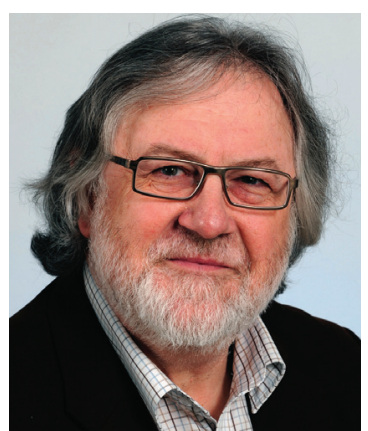

John A. Stotesbury

Tntentions. My primary intention in this paper is to continue an ongoing investigation into alternative ways of reading fictional narratives that have been produced in the English language and in a British context, but whose content has been shaped by a particular aspect of diasporic alterity: that of identities embedded in a belief system - Islam - that is not only self-evidently different from the historically dominant systems of mainstream British culture but also regarded - in largely illdefined ways - as potentially inimical to the perceived dominant cultural formation. Recent studies of diasporic writing such as Mark Stein's Black British Literature (Stein 2004) and John McLeod's Postcolonial London: Rewriting the Metropolis (McLeod 2004) have provided valuable discussions of the social, political and literarycultural realities of such writing, but neither critic pays attention to the vitality of diasporic Islam and its discursive presence as a major shaping factor within a growing body of new fiction in English.

The problematic of this paper will, in consequence, be developed in a brief discussion of the writing of an author, Leila Aboulela, whose origins are Sudanese and Egyptian - and closely linked with Muslim culture - but whose literary identity is primarily connected with the English language and Britain. My critical concern is with my perception of the potentially split reception of her fiction by a readership made up not only of members of the diasporic communities resident in Britain (and elsewhere) but also of a growing Western readership largely unschooled in Aboulela's personal cultural field, Islam. My present intention, however, is not to produce a more finely tuned reading of Aboulela's fiction per se, but to explore some of the more accessible implications in the ethical reception of her work by readers such as myself - white, Western European, culturally post-Christian, male, and (given that I have been educated in the broad field of literary and cultural studies) professionally responsible for mediating such literature to a relatively large number of students and fellow scholars.

For the present version of this paper, my frame of analytical reference has been shaped initially by Andrew Gibson's work on "Reception and Receptivity" in his larger study, Postmodernity, Ethics and the Novel: From Levinas to Leavis (1999:186-212). It must be emphasised, however, that, in its form, Aboulela's fiction is realist rather than postmodern, but like Gibson himself in his reference to several other diasporic novelists, I assume that Aboulela writes out of the "postmodern experience," which in her case can be 
readily identified as fragmented, disjunctive, subjective, and particular rather than participatory in any of the grand narratives of the past. My study is, however, predicated by a consciousness of developments in the ethics of reading and narration as they have emerged in recent studies of the narrative representation of trauma and memory. (Caruth 1995, 1996; Miller \& Tougaw 2002; Vickroy 2002) This sense of the intimate connections between the ethics of writing and reading, the postmodern and the diasporic narrative will, I believe, become increasingly apparent in the body of this paper.

Context. In the context of diasporic writing, Gibson emphasises "the oddity and the incompatibility, from one cultural perspective, of value-systems that are apparently congruent enough from another" (198). Gibson's immediate focus is on the potentially split readership of Timothy Mo's novel Sour Sweet (1982), the incongruities of whose reception reside, he suggests, precisely within the disjuncture between its cultural frame of reference, i.e., its implicit value-systems, and in its existence as a text produced in English rather than Cantonese, which might otherwise be regarded as the primary medium of the value-system represented in the novel. This condition provides a critical aporia, Gibson continues, that is symptomatic of the genre: Sour Sweet "inhabits a "split-space,"” and as such contains an "indeterminacy that is constitutive of the text and ineradicable" (199).

His second example looks at an alternative dilemma in the reception of Kazuo Ishiguro's A Pale View of the Hills (1982), which Gibson again problematizes in terms of its split reception (see $200 \mathrm{ff}$.). In according recognition to the twin dilemmas of "splitspace" and "split-time" in the reception of diasporic writing, he turns for their resolution to an alternative understanding of reception implicit in Karatani's (also Japanese) concept of tent?. Tent?, in Gibson's definition, is concerned primarily with decentring the centre, with fabricating "the moment at which one temporal logic is substituted for another" (203) - but, simultaneously, the substitution itself is also erased in an attempt to erase the historicity of the act of reception precisely because of its incongruity within the text.

At this level, links with trauma theory and diasporic literary narration appear both seductively straightforward but also, on one level - that of the emphatic historicity of most diasporic writing narratives - partially contradictory. Laurie Vickroy's introduction to the topic has been particularly valuable: "trauma narratives [...] raise important questions and responsibilities associated with the writing and reading of trauma as they position their readers in ethical dilemmas analogous to those of trauma survivors". Like Vickroy, Kai Erikson has also indicated the persuasive force of the concept of trauma, not merely as a physical or psychological wound but as a form of profound damage to the "tissues of community." (1995:185) Erikson's perception is of trauma as an ambivalent force that both "estranges" the individual in isolation from the world around but can also "create community." Trauma, in effect, becomes a "ghetto for the unattached," a site linking "otherwise unconnected persons who share a traumatic experience [and so] seek one another out and develop a form of friendship on the strength of that common tie" (186-87).

It is in this perception of estrangement linked with an apparently "falsely-based" sense of communality that I will attempt, briefly in what follows, to locate Leila Aboulela's representation of the experience of diaspora. 
Text: (Re-)Reading Aboulela. Amidst fiction published in Britain by women writers living in diaspora, Aboulela's is a new voice. She spent her childhood under privileged conditions in Khartoum, and despite her Arabic origins, English, her literary language, evidently became her medium of self-expression from her earliest years.

As I have described elsewhere, (Stotesbury 2004:69-82) Aboulela's writing has become largely British-centred. Her first novel, The Translator was written, set, and published in Scotland, where she lived for ten years in Aberdeen, while her second novel, Minaret, was not only published by a major metropolitan publisher, Bloomsbury, but is set principally in present-day London, although it also includes systematic flashbacks to the different Londons of twenty years ago and at the time of the first Gulf War in 1991. Its positive reception in reviews in the upmarket press suggests that Aboulela herself is gaining recognition in the general Western literary world rather than simply within academic and diasporic circles.

What is undoubtedly different in Aboulela's fiction is that it has consistently constructed a context and value-system for its protagonists that can be regarded as explicitly Islamic. Both The Translator and Minaret depict a personal religious faith that is uncompromisingly single-minded. More perplexingly from a Western receptive stance, both novels also argue for a perspective on Islam that denies the ultimate significance of the notion of geophysical, urban neighbourhood, replacing it instead with an absolute adherence to an alternative, definable, but also invisible and borderless "neighbourhood": Islam. Notable here is that, while contemporary popular Western readings of Islam frequently regard it as territorially expansive, Islamic opinion itself often appears to run counter to such ambitions. Although Aboulela never defines it as such, her own narrative representation of Islam suggests a re-definition of space as a global or universal habitus, unlimited by historical - colonial or postcolonial borderlines. As Aboulela has her (native Scottish) male protagonist in The Translator proclaim, "'Ours isn't a religion of suffering [...] nor is it tied to a particular place"” (179). Minaret, in its turn, continues the exploration of such an apparently contradictory notion within the realist context of present-day London.

As Mike Phillips has indicated in a press review, novels such as Minaret are also driven by the clash of values revealed in the most intimate of personal relationships. Minaret itself presents two love stories that fail, and one more (the spiritual "romance" of the woman's revived faith) that succeeds, though perhaps only provisionally. At the start of the story, Najwa, a girl born into a privileged, secularised and Westernised Khartoum family in 1965, is presented as an aimless, rich little girl who studies half-heartedly at the local university. There she comes into contact with a number of postcolonial tensions: she observes with some sense of guilt the piety of some of the poorer students, but she also embarks on a flirtatious relationship with a Communist student activist, who openly accuses her father of corruption. A political coup ensues, and Najwa finds asylum in London along with her twin brother Omar, her mother, and several uncles and their families. She and her brother become consumers of Westernism. They appear to adapt, although their adaptation to life in the West is inevitably "post-traumatic": a dual expression of enforced exile from Africa linked with estrangement from their Western metropolitan refuge, London. As Najwa records, "Our first weeks in London were OK. [...] The first thing we did was go to Oxford Street and buy 
clothes" (56). But once her father has been tried and executed in Sudan, things start to fall apart. Her father's overseas bank accounts deplete and Najwa is compelled to seek work, and like any inhabitant of London, she learns to navigate the city by travelling the Underground, reading the polychromatic coding of the routes on the city map like any other post-imperial citizen. Nevertheless, with the jailing of her brother for drug-trafficking, and with the death of their mother, it would seem that Najwa's experience of exile finally implodes into a meaningless condition of displacement and Western urban alienation.

At this point, in an apparent split-time sequence, the novel shifts forward to the London of 2003. Najwa now works for a wealthy but fragmented transnational Arab family in a capacity that is used explicitly to symbolize the reversal in her material fortunes: from spoilt and potential transnational she has descended socially to the condition of employed servant, housemaid and nanny. Her spatial vision of London routes has also shifted, from the concentric patterns of the inner-city Underground routes to routes that take her outwards from the city-centre, one route to Omar's prison, "nearing the end of the line" (91), where he has served almost fifteen years, and the other, equally appropriately, "at the end of the tube line" (138), to the cemetery where her mother lies buried.

As already suggested, Minaret is in significant ways a development out of - or away from - the general run of the diaspora fiction by women writers. On first reading, Minaret does indeed appear to portray a desire for unfettered agency on the part of the protagonist, but her quest is curiously complicated by her adherence to a belief in placelessness over place. Place nevertheless plays an important role in the novel, since it is within the context of London that the protagonist eventually discovers a physical space - the Central London Mosque - within which she can begin to re-discover her personal equilibrium.

Her conversion to a devout practice of Islam then triggers accounts in the novel of two romances, one earlier and the other resulting from her conversion, but both equally futile. The first occurs in the late 1980s, when after a subsequent coup in the Sudan, Anwar the Communist is himself driven into exile in London, where he contacts her. Najwa becomes involved in his exilic world of political journalism, and their relationship gains a sexual dimension, and she appears to have acquired a new transnational aspect to her identity:

"Tell me," he said, how many twenty-five-year-old girls in London are virgins?"

He was right, I was in the majority now, I was a true Londoner now. (176)

Her second romance starts a whole decade and a half later, when Najwa finds that the piety of her employer's brother, Tamer, a reluctant undergraduate business student twenty years her junior, attracts her into a chaste but increasingly passionate love affair. Like its predecessor, this affair is doomed, this time by the opposition of Tamer's family to the disparity in their ages. In her despair, Najwa accepts money from Tamer's family as a substitute for her potential young husband, consoling herself with the notion that now she will be able to afford to travel to Mecca for hajj.

Provisional conclusions. Most immediately, Minaret offers its readers a multiplicity of narrative perspectives that may be at once familiar and unfamiliar, depending on the receptive expectations of the individual reader. Generically, it proffers the various formulae of inspirational or devout fiction whilst simultaneously echoing the 
structures familiar in Western tales of romantic love - The Translator, for example, was consciously modelled on Jane Eyre, whilst Minaret explores an alternative romantic formula of "love betrayed." In addition to the traumas of exile and of her father's execution, Najwa's submission to a sexual affair with her father's betrayer is profoundly degrading. Her equally "confused" love affair, years later, with a devout fellow-Muslim twenty years her junior then compounds her personal degradation, from which she is rescued only by what amounts to a deus ex machina, when her potential lover's sister provides her with the financial means to undertake a spiritually cleansing hajj.

At its heart, however, Minaret appears to disrupt the critical identity of the Western reader with its obsession with space (Khartoum; London) whilst simultaneously adhering to a value-system, Islam, that defies adherence to spatiality. For the Sudanese protagonist, Najwa, London becomes not only the heart of her existential survival, but also its utter periphery, and this simultaneous inversion insists on subverting oversimplistic readings of this dour tale of thwarted romance.

Even more problematically, the novel concludes with an ambiguity that unexpectedly belies its devotional intent. Half waking, half sleeping, Najwa drifts into a stream of consciousness that differs substantially in style from the rest of the novel:

I am not well. I have a fever and I need my parents' room. I need their bed; its clean sheets, the privilege. I climb dark steep stairs to their room and there is the bed I have been fretting for. My mother's voice, her cool hand on her forehead. She gives me a spoonful of medicine, delicious cough syrup that burns my throat. Omar is sulking. He is jealous because I am ill and important. He wants something from me and Mama says, "Leave her alone, can't you see she's burning." I look up into my father's anxious face, his warm hand on my cheeks. I smell his cologne. He shouts at my mother, "Put her on a course of antibiotics, you can't leave her like this!" I roll over, luxurious, sure that they love me. Around us, beyond the bed, the room is dark and cluttered, all the possessions that distinguish us in ruins. I am not surprised. It is a natural decay and I accept it. Carpets threadbare and curtains torn. Valuables squashed and stamped with filth. Things that must not be seen, shameful things, are exposed. The ceiling has caved in, the floor is gutted and the crumbling walls are smeared with guilt. (276)

The ultimate dilemma - for the reader, especially the Western reader - is in the identification of the post-colonial trauma inhabited by the single exilic woman represented in Najwa. No longer "African" nor yet "Western," Najwa inhabits an ambiguous identity that impacts on us all with its relentless postmodernity. For Najwa, her existential refuge and respite from the trauma of exile is in her adherence to her "placeless" Islamic faith, while everything else in her existence - the Western metropolis, the decay of material things, and the inevitability (for Najwa) of a loveless life, with only her Islamic faith as consolation - remain for her a meaningful reality. For the postmodern Western reader "himself," however, there would seem to remain no such altern ative. 
Notes:

* $\quad$ "I say I am Sudanese, but my mother is Egyptian, I was born in Cairo, but that was only because my mother was visiting her parents. [...] I went to an American school in Khartoum when I was seven, yes it was unusual, I was there four years then I went to a private school and that was all in English and the University was in English." (Leila Aboulela (2004) Moving Away from Accuracy // The European English Messenger 13.1:72.

\section{References:}

1. Caruth, Cathy (ed.) (1995) Trauma: Explorations in Memory. Baltimore: John Hopkins UP.

2. Caruth, Cathy (1996) Unclaimed Experience: Trauma, Narrative, and History. Baltimore: John Hopkins UP.

3. Erikson, Kai (1995) Notes on Trauma and Community // Trauma: Explorations in Memory. / Caruth, C. (ed.). Baltimore: John Hopkins UP.

4. Gibson, Andrew (1999) Postmodernity, Ethics and the Novel: From Leavis to Levinas. London: Routledge.

5. McLeod, John (2004) Postcolonial London: Rewriting the Metropolis. London: Routledge.

6. Miller, Nancy K.; Jason Tougaw (eds.) (2002) Extremities: Trauma, Testimony and Community. Urbana: U of Illinois P.

7. Stein, Mark (2004) Black British Literature: Novels of Transformation. Columbus, $\mathrm{OH}$ : Ohio State University Press.

8. Stotesbury, J. (2004) Genre and Islam in Recent Anglophone Romantic Fiction // Refracting the Canon in Contemporary English Literature and Film. / Ed. by Onega, Susana; Gutleben, Christian. Amsterdam: Rodopi.

9. Vickroy, Laurie (2002) Trauma and Survival in Contemporary Fiction. Charlottesville: U of Virginia P.

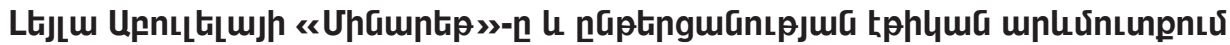

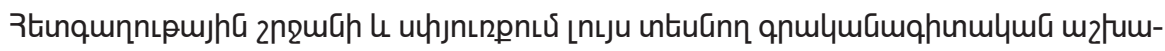

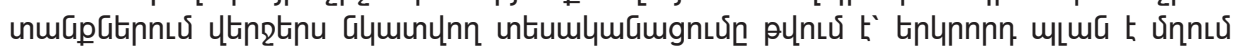

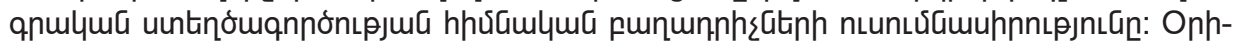

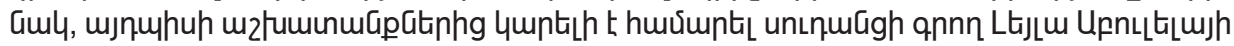

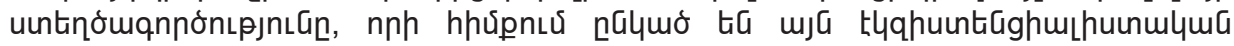

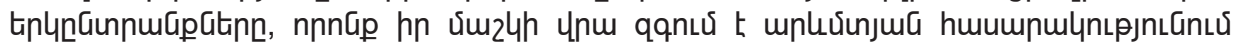

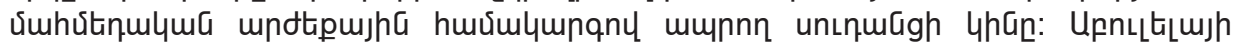

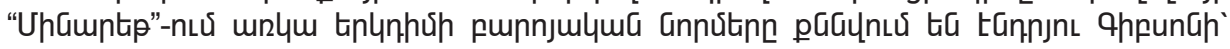

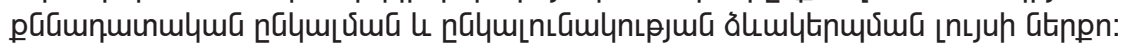

